they are engaged in, and must be prepared to defend it on that basis.

Racism is a political act, and scientific racism is simply the recruitment of the trappings of science in pursuit of its ignoble goals. If scientific racism has a place in science, it debases the entire enterprise.

Jonathan Marks Department of Anthropology, University of North Carolina at Charlotte, Charlotte, North Carolina 28223, USA

e-mail:jmarks@uncc.edu

\section{Would you wish the research undone?}

SIR - Rose offers a piece of moral advice in his Commentary. To instruct humankind that they should not do something is a serious undertaking: it should be clear what is enjoined and the consequences acknowledged.

Rose seems to argue that, by about 1975, it should have been clear to everyone that the question of genetic causes behind the black/white IQ gap was unanswerable. From that date, there was no excuse for Arthur Jensen or anybody else to persist.

I invite everyone to search the social-science literature of the past 34 years and ask whether or not they really wish that everything on the subject, pro or con, was missing. I thought that the first replies published to rebut Jensen were pathetic, and still do. Others must judge the value of my subsequent book Race, IQ and Jensen (Routledge \& Kegan Paul; 1980); the theory of intelligence that limits $g$ - the 'general intelligence factor' - to explaining individual differences; the Dickens-Flynn model of the interaction of genes and environment; the analysis of the achievements of ChineseAmericans, and so forth. More distinguished contributions have been made than those that I have offered.

Imagine that IQ tests showed black American children having, on average, a 15-point IQ advantage over white children. How many of us would denounce that finding as meaningless? Or would we be waving it like a banner, as evidence that only racists would attempt to dismiss? The scientifically respectable has a way of shifting, depending on how one thinks the debate is going.

As the philosopher John Stuart Mill points out, when you assert that a topic is not to be debated, you are foreclosing not some narrow statement of opinion on that topic, but the whole spiralling universe of discourse that it may inspire. Mill thought that only someone so self-deluded as to think his own judgement was infallible could wish to circumscribe an unpredictable future in this way.

Rose should be very certain he is correct. If not, and if he converts the rest of us, only Jensen and those of his persuasion will publish; and they will win the minds of students because the rest of us have all adopted a policy of unilateral disarmament.

Jim Flynn Box 56, University of Otago, New Zealand

e-mail:jim.flynn@otago.ac.nz

\section{Measured intelligence is a product of social processes}

SIR - 'Eugenics' is a word that most people believe has been consigned to history. The term makes us think of the horrors of Nazi Germany, or perhaps the sterilization of disabled people in places such as the United Kingdom, the United States and Sweden (see T. Shakespeare et al. Genetic Politics: From Eugenics to Genome New Clarion Press, 2002).

However, eugenic thinking also survives in contemporary education policy, in the belief that some children are simply 'brighter', 'smarter' or 'more able' than their contemporaries. In the US and UK systems, this assumption finds expression in schools' use of 'tracking'

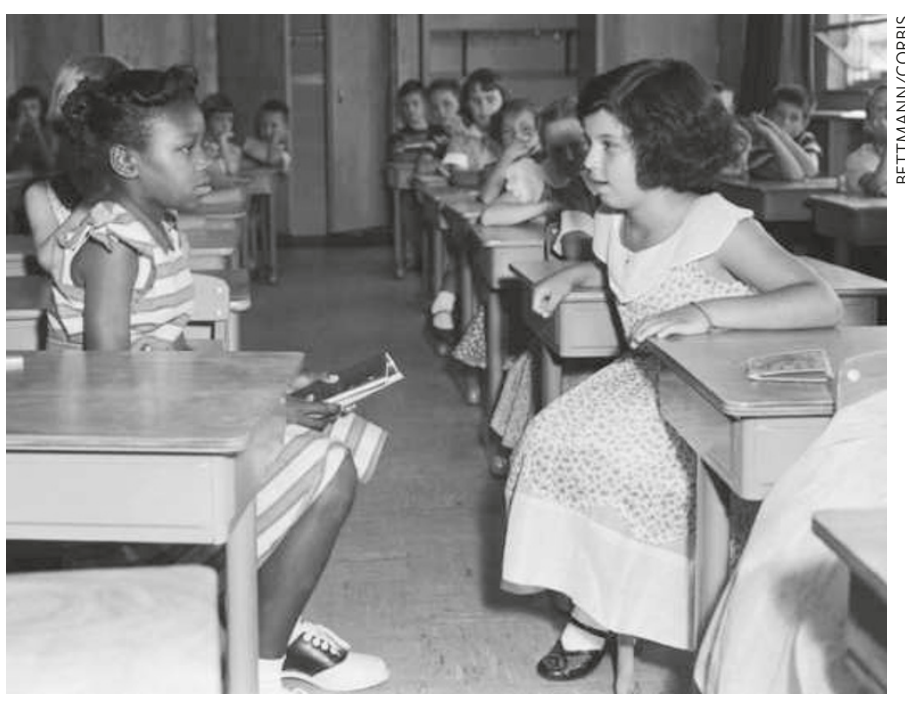

Do race and gender affect performance in the classroom?

and 'setting by ability', which separates children (from as early as the age of five in Britain) and sets them on very different paths.

Yet there is no way of measuring the limits of capability. Every test ever invented (whether an IQ test or a driving test) assesses only how well a person is currently able to perform certain tasks. Measured 'intelligence' is a product of social processes, not a determinant of them. The results often become self-perpetuating. Black children and their white peers from poor backgrounds are consistently over-represented in the lowest-ranked groups, where they cover less of the curriculum, are taught by less experienced teachers and make slower progress.

It is time that we were liberated from the racist and regressive ideas that have become so intrinsically bound up in the notion of intelligence. By finally having the courage to admit that contemporary patterns of class, race and gender inequity are wholly a product of our own policies and priorities, we might finally begin the urgent business of dismantling such injustice, rather than seeking to excuse it as an act of nature.

David Gillborn Institute of Education University of London, 20 Bedford Way, London WC1H OAL, UK

e-mail:d.gillborn@ioe.ac.uk

\section{Don't fan the flames of a dead debate}

SIR - Why study possible links between race, gender, genes and intelligence? In their Commentary, Ceci and Williams's response seems to be that it provokes good scientists to sharpen their critique of the poor science of those who ask that question, and that this advances the field. I agree; when, in the late eighteenth century, rival proponents of phlogiston and oxygen battled it out to account for combustion, the controversy was illuminating. But it was decisively settled, and within a decade phlogiston was dead. So too with race, gender and IQ. We had the debates some 30 years ago and, as Ceci and Williams agree, those who argued for genetic explanations for group differences (phlogiston theorists) lost. So why reignite a dead debate, unless it is to serve some sociopolitical, not scientific, end?

Ceci and Williams list some of those who have continued to insist that the issue is not closed, and defend them against the criticisms, and in some cases hostility, they have generated. To make their point, they invoke the spectre of Trofim Lysenko. The comparison is illuminating. Lysenko falsified experimental 
data in defence of politically expedient but mistaken theories, with damaging effects on Soviet agriculture. When in the 1940s his theories received Joseph Stalin's imprimatur, Soviet genetics, which had flourished through the 1920s and 1930s, was destroyed. But they have their comparison the wrong way round. In the present case it is the proponents of race-gender-IQ theories who are defending a mistaken but politically expedient theory, with potentially seriously damaging social consequences.

Ceci and Williams defend the principle of free speech; you should not be silenced for arguing for phlogiston, although your grant applications based on the theory are unlikely to be funded (except by Foundations for the Defence of Phlogiston, which certainly exist in the case of race, gender and IQ). But it is my impression that, far from being silenced, phlogiston theorists get quite a bit of time on air and in print. Freedom of speech should be defended, but it cannot be an unbounded freedom in cases where, more than just falsely crying "Fire!" in a crowded theatre, the speech provides the matches and petrol for those who are actively trying to set the place alight.

Steven Rose Open University, UK e-mail:S.P.R.Rose@open.ac.uk

\section{A useful way to glean social information}

SIR - Rose concludes by noting, when it comes to research on race, gender and IQ, that "there is no valid knowledge to be found in this area at all". Is the worldwide increase in IQ not valid, and should its insights into the malleability of racial differences in intelligence be ignored? Is the superiority of women's mathematical grades unimportant? Does the convergence of black and white test scores not inform our understanding of how to achieve a more just society? All of these findings stemmed from research that Rose claims is invalid.

One-party science may appease some now, but will eventually stymie scientific understanding. The recent renaissance of research on Lamarckian modes of genetic transmission shows that not all widely acknowledged 'dead' theories are $100 \%$ wrong Lamarck was dismissed years ago, but today his ideas spur valuable science.

Rose argues that a single $g$-loaded coefficient, such as an IQ score, cannot capture all of intelligence. We agree. However, the limitations of IQ are not a reason to muzzle researchers who believe that, albeit imperfect, it nevertheless provides important predictive information.

Rose argues that the dubious biological underpinnings of race render scientific analyses meaningless. Although we agree that the terms white, black, Caucasian or Asian do not define distinct races, this misses the point: self-defined race often provides the largest coefficient in models of achievement. Even if race is a proxy for a chain of social and environmental events that are not genetic, this does not minimize the scientific value of studying it. No one who selfdefines as black will deny that this identity is omnipresent in their own and others' consciousness, influencing social interactions and stirring identity threat. Most governments require reporting of racial gaps; numerous studies target narrowing them. Such factors justify studying race, even if it is entirely socially constructed.

The same goes for gender, which - as Rose points out - is highly influenced by socialization but nonetheless continues to offer important insights as a category. Empirical research reveals cognitive differences between the sexes in 4-month-old babies. Even if one argues that these infants' environment has already caused sex differences, this does not gainsay their empirical basis nor their scientific validity.

No one endorses pseudoscience, but Rose has prejudged what qualifies.

Wendy M. Williams, Stephen J. Ceci Department of Human Development, Cornell University, Ithaca, New York, USA e-mail:wmw5@cornell.edu

Further contributions are welcome online at $h t t p: / /$ tinyurl.com/askwhp.

\section{Human rights cannot cover cells that were never in the womb}

SIR - In his contribution to the Commentary 'Your inbox, Mr President', in which leading scientists provided advice to Barack Obama (Nature 457, 261; 2009), George Daley writes of the strong indication that the Obama administration will remove restrictions on federal funding for human embryonic stem-cell research. Although Daley recognizes the vital importance of this innovative research, he also illustrates the potential limitations and legislative or regulatory restrictions.

The controversial and moral question of when human life actually begins is the basis of limitations placed on work such as somatic-cell nuclear transfer or the derivation of new cell lines from embryos discarded from in vitro fertilization procedures. On 29 May 2008, the Brazilian Supreme Court approved legislation allowing stem-cell research. One of the arguments for this approval is that embryos that have already been frozen would never be implanted in the uterus.

Although many people affirm that human life begins when the sperm is impregnated into the egg, either naturally or artificially, they ignore the role of the uterus. Human status is attributed by some to 5-day-old embryos, which consequently would receive the same protection rights as any person. Do frozen and/or inviable embryos, which could never be implanted in a maternal uterus, deserve this status? To begin the process of forming a living human, there must be connection of an embryo to a mother's epithelial cells. This requires the interaction of the embryo with the endometrium (the wall of the uterus).

The Brazilian constitution states that the civil rights of a person begin at the moment of live birth. The law extends these neonate rights from the moment of conception - but only if the baby is born alive. A fertilized egg that is not implanted in the uterus is neither a neonate nor a person. According to traditional Roman law: "Nasciturus pro iam nato habetur, quotiens de commodis eius agitur", which translates as "The unborn child is treated as a child already born in all things respecting its interests". This was presumably conditional on its being born alive. If not, then this protection becomes obsolete.

For a human being to exist and to benefit from civil protection laws, the uterus is a crucial component.

Patricia Pranke Hematology and Stem Cell Laboratory, Federal University of Rio Grande do Sul, and Stem Cell Research Institute, Av Ipiranga, 2752, 304G, 90610-000, Porto Alegre, Brazil e-mail: patriciapranke@ufrgs.br João Carlos Silveiro Stem Cell Research Institute and Silveiro Advogados, Av Dom Pedro II, 1240 , 90550-141, Porto Alegre, Brazil 